\title{
Anjos de Macau na primeira década do século XX
}

\author{
Maria Célia Lima-Hernandes \\ Roberval Teixeira e Silva ${ }^{1}$
}

Há os anjos que todos conhecem. Também há os que só surgem de ações.

Estes são os anjos de Macau.

Resumo: Esse projeto, a partir de uma perspectiva linguístico-discursiva, histórica, cultural e social, procura iluminar, recuperar, apresentar, homenagear, através das narrativas de histórias de vida, sujeitos que trabalharam e trabalham para uma Macau e um mundo melhor nas suas diferentes áreas de atuação.

Palavras chave: narrativas; identidades; Macau.

\section{Introdução}

As cidades são construídas discursivamente. Há uma Macau construída em línguas chinesas, há uma Macau construída em línguas inglesas, há uma Macau construída em línguas portuguesas, há ainda outras "Macaus" construídas em diferentes línguas.

Seja qual for a Macau de que estejamos falando, há figuras na sua História que transitam em todas essas esferas urbanas, tecendo teias sob, sobre e entre essas diferenças. São personagens que muitas vezes, de forma anônima, cuidam desse espaço, dessas gentes, os quais vamos caracterizar como anjos de Macau. E os anjos têm uma vida que vale a pena ser narrada. Essas narrativas vão construindo o mundo desses anjos, o mundo das pessoas que os cercaram, vão reconfigurando, por fim, cada nova Macau que renasce com novos fatos históricos.

Recuperar as suas histórias e as suas obras pode revelar muito sobre as dinâmicas sociais que constituíram e constituem a RAEM. Esse é objetivo do Projeto "Anjos de Macau", que toma como meta a recuperação de microhistórias (teias) que foram se tecendo ao longo dos séculos XX e XXI, período

\footnotetext{
1 Maria Célia Lima-Hernandes é pesquisadora CNPq, Professora Associada da Faculdade de Filosofia, Letras e Ciências Humanas, da Universidade de São Paulo, pós-doutora pela Universidade de Macau e líder do grupo de pesquisa "Mudança Gramatical do Português Gramaticalização". Email: mceliah@usp.br. Roberval Teixeira e Silva é Professor Auxiliar do Departamento de Português da Universidade de Macau e Pesquisador do Centro de Estudos Luso-Asiáticos da Universidade de Macau na linha "Linguagem, Cultura e Interação". Email: robts@umac.mo
} 
de grande efervescência sociocultural em Macau, especialmente porque essa cidade experienciou por seus habitantes, sujeitos de processos históricos e socioculturais, impactos significativos de ações e de respostas dessas várias camadas de realidade social.

Organizamos este texto de modo a apresentar inicialmente vozes que consideram esse tipo de investigação arqueológico-discursiva, pois é das histórias relatadas que recolhemos pistas de ações pretéritas. Depois, passamos a um estudo de caso: o das irmãs canossianas, como ilustrativo dos objetivos do projeto Anjos de Macau.

\section{Fontes para um trabalho arqueológico-discursivo}

Relatos permitem reconstruir um momento, uma história, fragmentos de uma vida. Por meio deles podemos reconhecer atos e efeitos de ações que guardam em si a solidariedade que une grupos, conjuntos de pessoas que constituem uma comunidade. Como afirma Bastos (2004, p. 118), "nossas vidas diárias são povoadas de estórias. Contando estórias nos divertimos, sofremos, construímos relações com os outros, damos sentido ao mundo que nos cerca e a nós mesmos".

Através das histórias, construímos e veiculamos sociolinguisticamente identidades em interação. Schiffrin (1996, p. 169) já indicava que as "histórias são recursos para desenvolvermos e apresentarmos o eu como entidade psicológica e também como algo localizado dentro de um mundo social e cultural". A forma como organizamos as histórias denuncia uma matriz de normas, padrões, sentidos uma vez que "tanto o estilo quanto a substância das histórias são sensíveis a parâmetros de etnicidade: classe social, gênero, idade, região...".

Por outro lado, os relatos podem ter, adicionalmente, um caráter reflexivo, pois, como destacou Linde (1993), as histórias de vida permitem expressar nosso entendimento sobre nosso eu, sobre quem somos e sobre como performatizamos nossas identidades em interações específicas.

Nas narrativas, apresentamos a nós mesmos e aos outros segundo parâmetros culturais das nossas referências e os quais constroem o que costumamos chamar de realidades. A narrativa sobre o outro, em contrapartida, permite acessar posicionamentos assumidos em momentos anteriores e, a partir deles, acessar os efeitos presentes para o espaço e para a comunidade.

Sendo assim, as narrativas sobre a vida desses anjos abrem canais para termos acesso aos olhares que se construíram socialmente sobre eles, sobre as suas identidades, sobre suas ações cujos resultados ainda remanescem em ecos de identidades sociais, que assumimos como espaços abertos para

12 fragmentum, N. 35, parte I. Laboratório Corpus: UFSM, Out./ Dez. 2012 
performatizar imagens, posicionamentos, crenças, gostos... e elaborar mundos (HALL, 1997; MOITA LOPES, 2002).

Esse projeto, a partir de uma perspectiva linguístico-discursiva, histórica, cultural e social procura iluminar, recuperar, apresentar, homenagear esses sujeitos que trabalharam e trabalham para uma Macau e um mundo melhor nas suas diferentes áreas de atuação.

\section{Estudo de caso: as irmãs canossianas}

Em fins de 1873 e inícios de 1874, a irmandade canossiana cujo lema era "caridade na humildade e humildade na caridade", passou a se fazer presente em Macau. Antes desse período conhecido oficialmente, entretanto, já havia se instalado na cidade a Madre Teresa Lucian, uma estrangeira determinada a salvaguardar a juventude a fim de que as raízes étnicas da sociedade macaense se mantivessem.

Logo que a irmã chegou a Macau, fixou residência no bairro chinês próximo à igreja de Santo Antônio e ali foi construindo a sua obra. Seu interesse era oferecer educação às crianças chinesas e a partir disso cumprir a sua obra de caridade. Somente em 1889, dezesseis anos aproximadamente após sua chegada, conseguiu abrir o Colégio Santa Clara, mais tarde rebatizado Santa Rosa de Lima, com as canossianas na direção até 1893.

Numa terra de tufões e alvo de intensas provas, seu papel foi fundamental para auxiliar os chineses da terra e os fugitivos do continente.

No Asilo da Santa Infância, anexo à igreja de Santo Antônio, as irmãs fizeram um belo trabalho e ganharam a confiança e o respeito dos chineses. Por volta de 1895, uma grande epidemia de peste bubônica atingiu Macau. A irmã Lucian foi para esse front social em 1898, e ali viu serem abatidos aproximadamente 1200 chineses. 


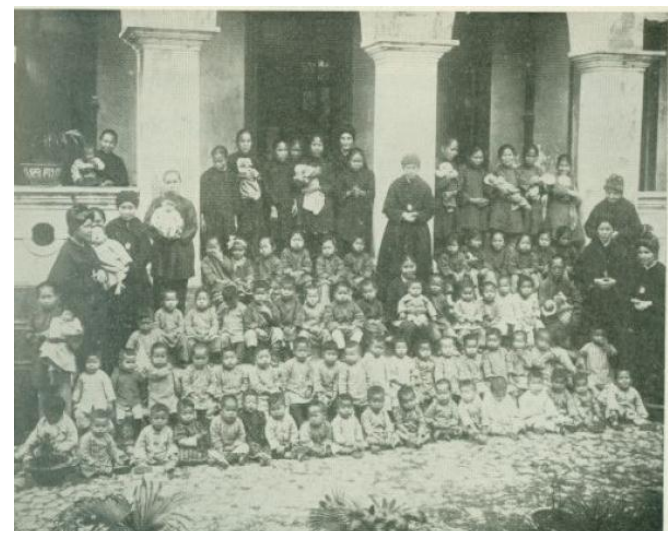

Figura 1 : Crianças do Santa Infância (1925).

Fonte: Arquivo Histórico de Macau.

Para se ter uma ideia do volume de trabalho assistencial que faziam as irmãs, somente no período de 1885 a 1951, foram recebidas 65.000 crianças, ou seja, em cada um dos 66 anos de atuação receberam em média 985 crianças por ano. A partir de 1952 até 1972, o número de crianças hospitalizadas é de 16.725, e um número dramático de abandonados é de 1.123 crianças chinesas ou mestiças, em sua maioria meninas.

\section{Histórias construindo uma cidade}

Personalidades, figuras, anjos como Madre Teresa são o foco da nossa atenção nesse projeto que se traduz na aventura de entender uma cidade a partir dos discursos narrativos que revivem e avivam as suas histórias.

\section{Referências}

BASTOS, Liliana. Narrativa e vida cotidiana. In SCRIPTA, Belo Horizonte, v. 7, n. 14, p. 118-127, $1^{\circ}$ sem. 2004.

BOLETIM ECLESIÁSTICO DE MACAU. Novembro de 1910 e fevereiro de 1911.

HALL, Stuart. A identidade cultural na Pós-Modernidade. Rio de Janeiro: DP\&A, 1997.

LINDE, Charllote. Life stories. Oxford \& New Yourk: Oxford University Press, 1993.

MOITA LOPES, L. P. da. Identidades fragmentadas. Campinas: Mercado de Letras, 2002.

14 fragmentum, N. 35, parte I. Laboratório Corpus: UFSM, Out./ Dez. 2012 
SCHIFFRIN, D. Narrative as self-portrait: Sociolinguistic constructions of identity. Language in society. Cambridge University Press,1996.

TEIXEIRA, Pe. Manuel. As canossianas na Diocese de Macau: cem anos de apostolado (1874-1974). Macau: Tipografia da Missão do Padroado, 1974. Disponível em:

<http://www.cccm.mctes.pt/bdigital/ebooks/B0040_Canossianas_item1/ind ex.html>. Acesso em: set.2012.

TEIXEIRA, Pe. Manuel. Macau e a sua diocese III: as ordens e congregações religiosas em Macau. Macau: Tipografia Soi Sang, 1961. 